\title{
English Manner of Speaking Verbs and their Italian Translations: A Cross-linguistic Comparison
}

\author{
By Roberta Mastrofini*
}

This study intends to analyze the different way in which Manner of Speaking verbs are construed in English and Italian. Following Talmy's distinction between Satellite-framed and Verb-framed languages, we aim at demonstrating how the semantic information conveyed by these verbs may be lost or enriched when switching from English into Italian. In order to do so, four contemporary English novels as well as their Italian translations were taken into account. 83 English MoS verbs were detected for a total of 776 occurrences. Their Italian counterparts (148 between verbs and multi-word constructions) were subsequently analyzed within the Generative Lexicon model (Pustevjosky, 1998). According to our results, English and Italian show a high degree of granularity in the semantic realization of Manner of Speaking verbs. Moreover, within this domain, the opposition between a Satellite-framed language like English and a Verb-framed language like Italian seems to be blurred, since both languages, more often than not, opt to conflate Manner in the verb root.

\section{Introduction}

This study investigates the domain of Manner of Speaking (henceforth $\mathrm{MoS}$ ) verbs in English and the way translators have dealt with them in Italian. In Talmy's (2000) cognitive-typological approach, manner is defined as one of the components for the description of a Motion Event. According to Talmy,

'the basic Motion event consists of one object (the Figure) moving or located with respect to another object (the reference object or Ground). It is analyzed as having four components: besides Figure and Ground, there are Path and Motion. The Path (with a capital P) is the path followed or site occupied by the Figure object with respect to the Ground object. The component of Motion (with a capital $M$ ) refers to the presence per se of motion or locatedness in the event. [...] In addition to these internal components, a Motion event can be associated with an external Co-event that most often bears the relation of Manner or Cause to it.' (Talmy 2000:25-26).

\footnotetext{
*Assistant Professor, Department of Humanities, University of Perugia, Italy.
} 
According to this definition, Manner refers to a subsidiary action or state that an Agent (or a Patient) performs together with its main action or state.

Talmy's work on Satellite-framed (henceforth S-F) and Verb-framed (henceforth V-F) languages identifies a two-category typology on the basis of the characteristic pattern in which the conceptual structure of a motion event is mapped onto syntactic structure. Briefly, S-F languages like English, and other Germanic languages, will prefer constructions in which the path of motion is expressed outside the verb root in a separate satellite, and will be high-manner salient. On the other hand, V-F languages like Italian, and other Romance languages, will prefer constructions in which the path is conflated in the verb root, and will be low-manner salient with a tendency to express manner in an adjunct construction, usually adverbials, gerundives or prepositional phrases.

After Talmy (2000), manner has been taken into consideration in a large number of contributions, all focusing on the domain of Manner of Motion verbs, albeit in different areas of research ${ }^{1}$. MoS verbs represent quite a new area of research that is worth pursuing, especially because cross-linguistic differences do seem to exist in the lexicalization of this domain of experience (see, among others, Lehrer 1988; De Mauro 1999).

In this study we intend to examine the way English and Italian MoS predicates encode Manner as well as the degree and type of information that is either lost or gained in the translation process between these two languages. This analysis is carried out using the Generative Lexicon Model proposed in Pustejovsky (1998). According to this model, the semantics of a lexical item can be defined as a structure, consisting of four levels of analysis and representation:

a) the Argument Structure, accounting for the number and type of arguments taking part in the syntactic realization of a predicate;

b) the Event Structure, which defines the event type underlying the predicate;

c) the Qualia Structure, that includes 'that set of properties or events associated with a lexical item which best explain what that word means' (Pustejovsky 1998:77);

d) the Lexical Inheritance Structure, which identifies how a lexical structure is connected to others in the type lattice, 'and its contribution to the global organization of a lexicon' (Pustejovsky 1998:61).

Inspired by Moravcsik's (1973) interpretation of Aristotle's modes of explanations ( $\tau \alpha \alpha \imath \tau \imath \alpha$ ), Pustejovsky's Qualia Structure refers to four essential

\footnotetext{
${ }^{1}$ For linguistic typology see Strömqvist \& Verhoeven 2004; Iacobini 2010, among others. For psycholinguistics see Li \& Gleitman 2002; Papafragou, Massey \& Gleitman 2006; Papafragou \& Selimis 2010. For second language acquisition research see Choi \& Bowerman 1991; Cadierno \& Ruiz 2006; Pavlenko 2010. For discourse analysis and rhetoric see Slobin (1996a, 1996b, 1997, 2000, 2005), Strömqvist \& Verhoeven 2004.
} 
aspects of a word's meaning: Constitutive, Formal, Telic, and Agentive. The first one accounts for the relation between an object and its constituent parts; the second distinguishes it within a larger domain; the third defines its purpose and function; the fourth refers to the factors involved in its origin or bringing it about (see Pustejovsky 1998:76). According to this level of analysis, the meaning of the verb to snivel can be represented as the act of saying something, in a high pitch, with a dissatisfied attitude, and the purpose to complain, as reported in (1).

(1) to snivel

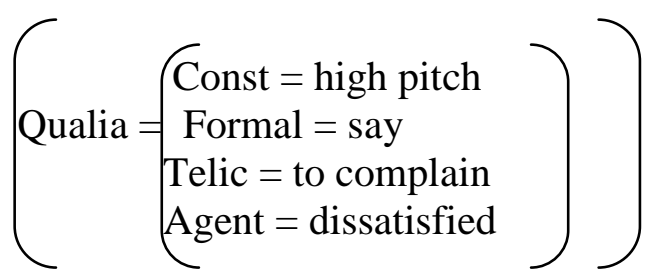

This kind of representation will vary according to the degree of semantic granularity encoded in the lexical item. In other words, not all qualia may be specified, as illustrated in the example provided in (2), where both the Agentive and the Telic qualia cannot be defined.

(2) to shout

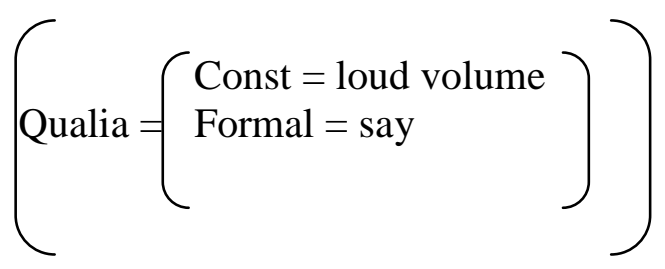

In this research, I use the Qualia Structure to identify and explain the semantic configuration of MoS verbs both in English and Italian. This level of analysis and representation was chosen in that it best illustrates the various semantic-pragmatic and physical auditory components that specify the speaking event underlying a MoS predicate.

This paper is organized as follows: $\$ 2$ briefly discusses the previous contributions on the topic; $\S 3$ describes the methodology used to achieve the results that are presented in $\S 4$. $\$ 5$ will be devoted to the discussion. $\S 6$ presents the conclusion. 


\section{Review of Previous Research}

The recognition of a subset of English predicates named "Manner of Speaking verbs" goes back to the work of Zwicky (1971). Since then, interest in this semantic domain has emerged in Mufwene (1978), Snell-Hornby (1983), Levin (1993), Urban and Ruppenhofer (2001), and Rojo and Valenzuela (2001). The only work that has dealt with MoS verbs from a contrastive perspective is Rojo and Valenzuela's (2001). Following Slobin's (1996) work on English and Spanish manner of motion verbs, they analyze the possible gain or loss of information when translating MoS verbs from English into Spanish. Strikingly enough, and in contrast to Slobin's findings, they show how relevant the semantic information conveyed by MoS verbs is, and therefore, when translating from a S-F language like English to a V-F one like Spanish it is often maintained or, even, supplemented. These results are really interesting, in that they give evidence of a different behavior of MoS verbs with respect to Manner of Motion verbs at a cross-linguistic level. Moving from Rojo and Valezuela's (2001) study, my contribution intends to investigate the same topic in English and Italian, given that, to the best of my knowledge, no V-F language other than Spanish has undergone such an investigation so far.

\section{Methodology}

My analysis starts from a corpus of $176 \mathrm{MoS}$ verbs, selected and presented in Vergaro, Sandford, Mastrofini, Formisano (forthcoming) ${ }^{1}$. Partly in keeping and partly refuting the previous contributions on the topic, Vergaro et al.'s study proposes a fine grained description of how English MoS verbs are construed. Their verb collection combines the lists found in previous works and all the synonyms found in dictionary. $\mathrm{com}^{2}$ and wordreference.com ${ }^{3}$. The corpus was then expanded by consulting a number of dictionaries (Oxford English Dictionary, Oxford Dictionary of English, Collins Cobuild English Dictionary, Macmillan English Dictionary, Longman Language Activator, New Oxford American English Dictionary) and through additional consultation of native speakers, thus resulting in the most complete and accurate list of MoS verbs existing in literature. This list is provided in Table 1.

\footnotetext{
${ }^{1}$ I am grateful to Vergaro et al. for giving me full access to their unpublished paper.

${ }^{2}$ Dictionary.com includes multiple dictionary listings - Dictionary.com Unabridged Based on the Random House Dictionary, (C) Random House, Inc. 2011, Collins World English Dictionary, Visual Thesaurus (Copyright (C1998-2011 Thinkmap, Inc.) and Etymonline.

${ }^{3}$ WordReference.com is based on the Concise Oxford English Dictionary, which offers more than 240,000 words, phrases, and meanings, as well as detail into the etymology of words in the English language. It is also linked to dictionary.com and Merriam.Webster (merriamwebster.com).
} 
Table 1. List of English MoS verbs in Vergaro et al. (forthcoming)

Admonish, Babble, Badger, Bark, Bawl, Bay, Bellow, Bellyache, Bemoan, Berate, Bicker, Bitch, Blab, Blare, Blather, Bleat, Bloviate, Blubber, Blurt, Boast, Boom, Brag, Bray, Bumble, Burble, Buzz, Cackle, Call, Carol, Carp, Chant, Chat, Chatter, Chide, Chipper, Chirp, Chirrup, Chitchat, Clack, Clamor, Confabulate, Coo, Croak, Croon, Crow, Cry, Declaim, Decry, Din, Discourse, Drawl, Drivel, Drone, Drool, Ejaculate, Exclaim, Falter, Gab, Gabble, Gibber, Gripe, Groan, Grouch, Growl, Grumble, Grunt, Gush, Hail, Harangue, Hiss, Holler, Hoot, Howl, Intone, Jabber, Jaw, Jeer, Kvetch, Lament, Lilt, Lisp, Maunder, Moan, Mock, Mouth, Mumble, Murmur, Mutter, Nag, Natter, Objurgate, Orate, Palaver, Pant, Patter, Peal, Perorate, Pipe, Plead, Pontificate, Prate, Prattle, Prod, Purr, Quack, Rabbit, Rage, Rail, Ramble, Rant, Rap, Rattle, Rave, Retort, Roar, Rouse, Rumble, Schmooze, Scold, Scream, Screech, Sermonize, Shout, Shriek, Shrill, Sibilate, Sigh, Singsong, Slur, Snap, Snarl, Snivel, Snort, Snuffle, Sob, Spiel, Spit, Splutter, Spout, Sputter, Squabble, Squall, Squawk, Squeak, Squeal, Stammer, Storm, Stumble, Stutter, Susurrate, Tattle, Thrum, Thunder, Trill, Trumpet, Twaddle, Twang, Twitter, Ululate, Vociferate, Waffle, Wail, Wheedle, Wheeze, Whimper, Whine, Whisper, Whoop, Wrangle, Yak, Yammer, Yap, Yell, Yelp, Yodel, Yowl

In Vergaro et al.'s study, each verb is described going beyond just the physical auditory components considered in previous research, and includes and accounts for semantic-pragmatic components as well. Vergaro et al.'s list was used in this paper to interrogate a corpus of four English contemporary novels and their translations into Italian. The novels are:

Harry Potter and the Sorcerer's Stone, 1997, by J. K. Rowlings (Harry Potter e la pietra filosofale, translated by M. Astrologo);

Harry Potter and the Chamber of Secrets, 1998, by J. K. Rowlings

(Harry Potter e la camera dei segreti, translated by M. Astrologo);

Disgrace, 1999, by J. M. Coetzee (Vergogna, translated by G.

Bona);

Elizabeth Costello, 2003, by J. M. Coetzee (Elizabeth Costello, translated by M. Baiocchi).

I searched for each of the $176 \mathrm{MoS}$ verbs singled out by Vergaro et al. in the four English novels, and then compared them with the Italian translations.

Unlike Rojo \& Valenzuela's work, very general verbs such as speak, say, tell or talk were not considered, since they do not express the manner in which something is said, but the mere act of saying. They did not prove to be useful, thereby, for the sake of this analysis.

\section{Analysis and Results}

Table 2 shows the results of my analysis. The first column presents the English MoS verb types found in the corpus of contemporary novels; the second column provides the number of occurrences (\#) for each verb type; the third column gives the translations of these verbs in Italian. 83 out of the 176 
English MoS verbs were detected in the corpus for a total of 776 occurrences, which were translated into 148 different Italian MoS verb types or multi-word constructions.

Table 2. Types and Occurrences of English MoS verbs and their Translations into Italian

\begin{tabular}{|c|c|c|}
\hline MoS Verb & \# & Translations as found in the corpus (Italian novels) \\
\hline Admonish & 2 & ammonire \\
\hline Bark & 9 & latrare, tuonare, sbraitare, abbaiare, ringhiare, gridare \\
\hline Bawl & 2 & urlare \\
\hline Bellow & 13 & intonare, gridare, esclamare, ruggire \\
\hline Berate & 1 & sgridare \\
\hline Bicker & 1 & battibeccare \\
\hline Blab & 1 & spiattellare \\
\hline Blurt & 4 & sbottare, farfugliare, chiedere d'impulso \\
\hline Boast & 4 & vantarsi \\
\hline Boom & 2 & sbottare, tuonare \\
\hline Buzz & 1 & mormorare \\
\hline Cackle & 4 & chiocciare, emettere uno squittio di contentezza \\
\hline Call & 56 & $\begin{array}{l}\text { gridare, annunciare, avvertire, apostrofare, chiedere, dire, } \\
\text { chiamare, salutare, invocare, fare appello }\end{array}$ \\
\hline Chat & 1 & chiacchierare \\
\hline Chatter & 1 & straparlare \\
\hline Croak & 13 & $\begin{array}{l}\text { gracchiare, dire con voce strozzata, supplicare con voce roca, } \\
\text { chiocciare, dire con voce arrochita, chiedere con voce roca, } \\
\text { rispondere, gracidare }\end{array}$ \\
\hline Croon & 1 & cantilenare \\
\hline Cry & 6 & gridare, sbottare, urlare \\
\hline Discourse & 1 & parlare \\
\hline Drawl & 3 & esclamare strascicando le parole, dire con voce strascicata \\
\hline Drone & 5 & parlare senza posa con voce monotona, dilungarsi \\
\hline Exclaim & 2 & esclamare, sbottare \\
\hline Falter & 7 & esitare, balbettare \\
\hline Gibber & 3 & farfugliare \\
\hline Groan & 11 & gemere, lamentarsi, grugnire \\
\hline Growl & 16 & ringhiare, rimbeccare, brontolare, grugnire, ruggire, urlare \\
\hline Grumble & 2 & borbottare, bofonchiare \\
\hline Grunt & 10 & grugnire, borbottare, farfugliare, bofonchiare \\
\hline Harangue & 1 & fare la predica \\
\hline Hiss & 20 & sibilare, sussurrare \\
\hline Hoot & 2 & chiurlare \\
\hline Howl & 11 & strillare, urlare, ululare dalla disperazione, gemere, ululare \\
\hline Intone & 1 & intonare \\
\hline Jabber & 2 & berciare, ciarlare \\
\hline Jaw & 1 & blaterare \\
\hline Jeer & 4 & schernire \\
\hline Lament & 2 & lamentare, gemere \\
\hline Moan & 12 & $\begin{array}{l}\text { piangere, dire sconfortato, sospirare, piagnucolare, } \\
\text { lamentarsi, bofonchiare, dire con voce lagnosa, mugolare, } \\
\text { gemere }\end{array}$ \\
\hline Mock & 3 & sfottere \\
\hline Mouth & 3 & articolare, sussurrare, bisbigliare \\
\hline Mumble & 13 & bofonchiare, borbottare, balbettare \\
\hline
\end{tabular}




\begin{tabular}{|c|c|c|}
\hline Murmur & 26 & mormorare \\
\hline Mutter & 44 & $\begin{array}{l}\text { borbottare, bofonchiare, balbettare, chiedere piano, } \\
\text { mormorare, bisbigliare, sbottare, accennare bofonchiando, } \\
\text { imprecare, dire a bassa voce, pronunciare }\end{array}$ \\
\hline Nag & 10 & angustiare, tormentare, disturbare, punzecchiare, pungolare \\
\hline Pant & 14 & $\begin{array}{l}\text { ansimare, esclamare ansimando, dire ansimante, dire } \\
\text { ansimando }\end{array}$ \\
\hline Pipe & 2 & dire con voce stridula \\
\hline Plead & 8 & scongiurare, supplicare, implorare \\
\hline Prattle & 1 & cianciare \\
\hline Rage & 1 & redarguire \\
\hline Rant & 4 & attaccare, sbraitare \\
\hline Retort & 3 & ribattere, replicare, rimbeccare \\
\hline Roar & 15 & $\begin{array}{l}\text { tuonare, ruggire, emettere un ruggito, tuonare con voce } \\
\text { stentorea }\end{array}$ \\
\hline Rumble & 1 & tuonare \\
\hline Scream & 22 & gridare, urlare, cacciare un urlo \\
\hline Screech & 4 & gridare con voce stridula, urlare, gridare, strillare \\
\hline Shout & 86 & $\begin{array}{l}\text { urlare, strillare, gridare, incitare, sgolarsi, esclamare, } \\
\text { sbraitare, lanciare un grido, parlare, fare un urlaccio, } \\
\text { sgridare }\end{array}$ \\
\hline Shriek & 15 & strillare, strepitare, gridare, emettere un grido stridulo \\
\hline Sigh & 25 & sospirare, gemere, dire con un sospiro di sollievo \\
\hline Slur & 1 & ingiuriare \\
\hline Snap & 35 & $\begin{array}{l}\text { aggredire, sbottare, azzannare, incalzare, rimbeccare, } \\
\text { interrompere, intimare, chiedere aspro, apostrofare aspramente, } \\
\text { ordinare secco, esclamare, ribattere seccato, precisare impaziente }\end{array}$ \\
\hline Snarl & 14 & $\begin{array}{l}\text { ringhiare, intimare, sbraitare, dire con tono aggressivo, ribattere, } \\
\text { dire con tono adirato, sbottare, dire in modo sarcastico }\end{array}$ \\
\hline Snort & 5 & sbuffare, grugnire \\
\hline Sob & 13 & singhiozzare, sospirare \\
\hline Spit & 2 & sbottare \\
\hline Splutter & 3 & esclamare, farfugliare \\
\hline Sputter & 2 & farfugliare \\
\hline Squall & 1 & strillare \\
\hline Squawk & 2 & strillare, dire con voce stridula \\
\hline Squeak & 8 & squittire, strillare \\
\hline Squeal & 11 & squittire, gridare, strillare \\
\hline Stammer & 8 & balbettare \\
\hline Storm & 2 & aggredire, gridare \\
\hline Stumble & 1 & continuare cocciuto \\
\hline Stutter & 6 & balbettare \\
\hline Thunder & 6 & tuonare \\
\hline Wail & 7 & lanciare alti lamenti, gemere, lagnarsi, dire gemendo \\
\hline Wheedle & 1 & incoraggiare \\
\hline Wheeze & 1 & intimare ansimando \\
\hline Whimper & 6 & frignare, lamentarsi, gemere \\
\hline Whine & 3 & chiedere piagnucolando, gemere \\
\hline Whisper & 63 & $\begin{array}{l}\text { bisbigliare, sussurrare, mormorare, sibilare, chiedere in un } \\
\text { bisbiglio, biascicare, sussurrare con un filo di voce, spiattellare a } \\
\text { bassa voce, dire in un sussurro, chiedere a bassa voce, chiedere in } \\
\text { un sussurro, sussurrare in un soffio }\end{array}$ \\
\hline Whoop & 2 & ululare, gridare d'entusiasmo \\
\hline Yell & 35 & gridare, urlare, sgolarsi, strillare, lanciare un grido \\
\hline
\end{tabular}


As a general overview, the Italian MoS verb types found in the corpus outnumber the English MoS verbs. More specifically, Italian translators used $148 \mathrm{MoS}$ verb types or multi-word constructions to represent the meaning conveyed by the 83 English counterparts found in the original novels. With a few exceptions, that is, 32 verbs out of 83 , all the other MoS verbs were translated using a minimum of 2 up to a maximum of 13 synonyms or synonymic multi-word expressions. These preliminary results give a clear idea of the degree of granularity of this semantic domain in Italian verb types. Moreover, this finding is in contrast to those presented in studies on Manner of Motion verbs (see, among others, Slobin 2005), according to which S-F languages normally employ a larger number of manner verbs than V-F languages.

In order to analyze the strategies used by the Italian translators, and to investigate the possible loss or gain of information due to the different way in which English and Italian conflate manner in MoS verbs, I grouped the 148 Italian translations found in the corpus into the following five categories:

1) MoS verbs;

2) general verbs of saying + an adjunct ${ }^{1}$ construction;

3) MoS verbs + an adjunct construction;

4) light verb constructions ${ }^{2}$;

5) general verbs of saying.

Table 3 illustrates the type and number ${ }^{3}$ of predicates fitting into each category. The first column presents the five categories detected on the basis of the different strategies adopted by the Italian translators; the second column lists a few examples found in the novels; the third column shows the total number of examples found; the fourth column provides the percentage out of the total of $148 \mathrm{MoS}$ verb types or multi-word constructions used in the Italian translations.

\footnotetext{
${ }^{1}$ The term "adjunct" is used as an hypernym to refer to any construction that involves syntactic elements additional to the verb (i.e. gerundives, adverbials, prepositional phrases).

${ }^{2}$ The notion of Light Verb Construction was first proposed by Jespersen who recognized 'the general tendency of Modern English to place an insignificant verb, to which the marks of person and tense are attached, before the really important idea' (Jespersen 1954:117-118). For more recent studies on this topic see, among others, Alba Salas 2002; Samek-Lodovici 2003; Alonso Ramos 2004; De Miguel 2008.

${ }^{3}$ The number refers only to the verb type, not to the number of times the same predicate occurs in the Italian translations.
} 
Table 3. Italian Translations of English MoS Verbs Grouped According to the Different Translation Strategies Adopted

\begin{tabular}{|c|c|c|c|}
\hline Category & Examples & $\#$ & Percentage \\
\hline MoS verbs & $\begin{array}{l}\text { ammonire, latrare, } \\
\text { piangere, sospirare, } \\
\text { attaccare, sbraitare, } \\
\text { ribattere, replicare }\end{array}$ & 94 & $64 \%$ \\
\hline $\begin{array}{c}\text { General verbs of } \\
\text { saying }+ \text { an adjunct } \\
\text { construction }\end{array}$ & $\begin{array}{c}\text { chiedere aspro, dire } \\
\text { ansimante, dire } \\
\text { ansimando, chiedere in } \\
\text { un bisbiglio, dire in un } \\
\text { sussurro, chiedere a } \\
\text { bassa voce }\end{array}$ & 25 & $17 \%$ \\
\hline $\begin{array}{l}\text { MoS verbs }+ \text { an } \\
\text { adjunct construction }\end{array}$ & $\begin{array}{l}\text { apostrofare aspramente, } \\
\text { ordinare secco, ribattere } \\
\text { seccato }\end{array}$ & 16 & $11 \%$ \\
\hline $\begin{array}{l}\text { Light Verb } \\
\text { Constructions }\end{array}$ & $\begin{array}{l}\text { fare appello, cacciare un } \\
\text { urlo, emettere un } \\
\text { ruggito, lanciare un } \\
\text { grido, fare un urlaccio, }\end{array}$ & 8 & $5 \%$ \\
\hline $\begin{array}{c}\text { General verbs of } \\
\text { saying }\end{array}$ & $\begin{array}{l}\text { chiedere, dire, } \\
\text { rispondere, parlare }\end{array}$ & 4 & $3 \%$ \\
\hline
\end{tabular}

As shown in Table 3, the category of MoS verbs is the most representative of the corpus of Italian translations ( $64 \%$ of the total, that is 94 examples out of 148). The next two most significant percentages ( $17 \%$ and $11 \%$, respectively) refer to more complex translation strategies, which involve both a predicate and an adjunct construction. $17 \%$ of the times (that is, 25 examples out of 148) the Italian translators choose a general verb of saying, and conflate Manner in the adjunct construction; whereas $11 \%$ of the times (that is, 16 examples out of 148) the verb root itself incorporates Manner while the adjunct construction conveys extra information regarding specific components of the speaking event, such as the speaker's attitude or intention, and the physical quality of the sound. With regard to the remaining strategies, a rather small number of light verb constructions (5\%, that is 8 examples out of 148) is used to translate the corresponding English MoS verbs. Moreover, very few instances of general verbs of saying were observed in the Italian corpus (3\%, that is 4 examples out of 148), thus, the translators rarely opt for the loss of information about Manner of Speaking.

In the following section, the results of our analysis are discussed, adopting Pustejovsky's (1998) Qualia Structure as an analytic tool.

\section{Discussion}

In this section, Pustejovsky's (1998) Qualia Structure is applied to the analysis of the Italian MoS verbs or multi-word constructions detected in the 
corpus. As for the different translation strategies adopted, the largest category is that of MoS verbs. In other words, translators replaced an English MoS verb with an Italian one $64 \%$ of the times, thus opting to conflate Manner of Speaking in the verb root.

For instance, comparing the semantic configuration of the verbs to whimper and frignare, we observe that every single component encoded in the English predicate is maintained in the Italian counterpart, as illustrated in (3).

(3) to whimper-frignare

$$
\left(\text { Qualia }=\left(\begin{array}{l}
\text { Const }=\text { low, continuous } \\
\text { Formal }=\text { say } \\
\text { Telic }=\text { to complain } \\
\text { Agent }=\text { unhappy or } \\
\text { physiological reaction }
\end{array}\right)\right)
$$

In a few other cases, though, the semantic configuration of the English MoS verb does not entirely correspond to that of the Italian MoS verb, in such a way that either the former does not encode some information expressed in the latter, or the other way round. The translation is thus partial. Examples of this sub-class are given in (4) and (5), respectively.

(4) to bawl

$$
\left(\text { Qualia }=\left(\begin{array}{l}
\text { Const }=\text { loud volume } \\
\text { Formal }=\text { say } \\
\text { Telic }=\text { to complain/ to persuade } \\
\text { Agent }=\text { annoyed }
\end{array}\right)\right.
$$

(5) to shout

$$
\left(\text { Qualia }=\left(\begin{array}{l}
\text { Const }=\text { loud volume } \\
\text { Formal }=\text { say }
\end{array}\right)\right)
$$

As for the example reported in (4), Italian translators used the verb urlare (literally, to yell, to shout), thus omitting the semantic components related to the Agentive and Telic qualia. On the other hand, the English MoS predicate to 
shout (5) is sometimes translated as incitare (literally, to incite), thus adding extra information regarding the positive attitude of the speaker (Agentive quale) and the purpose of the action (Telic quale $=$ to support). This asymmetry was observed only in a small number of examples (11 out of 94), therefore it can be ascribed to the translators' arbitrariness.

$28 \%$ of the times, however, English MoS verbs were translated into more complex syntactic constructions, involving both a predicate and an adjunct construction. $17 \%$ of the times the predicate is represented by a general verb of saying, thus translators choose to encode Manner only in the adjunct construction, as shown in example (6).

(6) to snarl - dire con tono aggressivo

$$
\left(\text { Qualia }=\left(\begin{array}{l}
\text { Const }=\text { loud volume } \\
\text { Formal }=\text { say } \\
\text { Telic }=\text { to warn } / \text { to intimidate } \\
\text { Agent }=\text { angry }
\end{array}\right)\right.
$$

As (6) exemplifies, the Italian general verb of saying dire (literally, to say) only realizes the information encoded in the Formal quale, whereas the physical auditory and semantic-pragmatic components of the Manner of speaking event (that is, the Constitutive, Telic and Agentive qualia) are incorporated in the adjunct construction.

On the other hand, in 16 examples out of 148 (that is, $11 \%$ of the times) both the verb and the adjunct construction incorporate Manner, as illustrated in (7) and (8).

(7) to croak - supplicare con voce roca

$$
\left(\text { Qualia }=\left(\begin{array}{l}
\text { Const }=\text { low, rough } \\
\text { Formal }=\text { say } \\
\text { Telic }=\text { to complain, to lament }
\end{array}\right)\right)
$$

(8) to whoop - gridare d'entusiasmo

$$
\left(\text { Qualia }=\left(\begin{array}{l}
\text { Const }=\text { loud volume } \\
\text { Formal }=\text { say } \\
\text { Agent }=\text { excited }
\end{array}\right)\right)
$$


In (7), both the Formal and the Telic qualia are licensed by the verb root, while the adjunct selects and emphasizes the physical auditory component of the speaking event (the Constitutive quale $=$ low, rough). In (8), the Formal and Constitutive qualia are encoded in the verb root, while the adjunct realizes the speaker's attitude (Agentive quale $=$ excited).

With regard to the use of light verb constructions, both the English MoS verb and the Italian multi-word expression realize the same semantic configuration of the speaking event, even though an additional aspectual specification is present in the Italian counterpart, as shown in $(9 a, b)$ and (10a, b).

(9a) to yell

$$
\left(\text { Qualia }=\left(\begin{array}{l}
\text { Const }=\text { loud volume } \\
\text { Formal }=\text { say }
\end{array}\right)\right)
$$

(9b) lanciare un grido

$$
\left(\text { Qualia }=\left(\begin{array}{l}
\text { Const }=\text { loud volume }[+ \text { telos }] \\
\text { Formal }=\text { say }
\end{array}\right)\right)
$$

(10a) to roar

$$
\left(\text { Qualia }=\left(\begin{array}{l}
\text { Const }=\text { loud volume } \\
\text { Formal }=\text { say }
\end{array}\right)\right)
$$

(10b) emettere un ruggito

$$
\left(\text { Qualia }=\left(\begin{array}{l}
\text { Const }=\text { loud volume }[+ \text { telos }] \\
\text { Formal }=\text { say }
\end{array}\right)\right)
$$

Whereas the English MoS examples (9a and 10a, respectively) denote an Activity verb, the Italian light verb constructions turn the Aktionsart ${ }^{1}$ of the

${ }^{1}$ For the notion of Aktionsart see Vendler 1967. 
verb from Activity into Accomplishment, thus describing both the process (to yell and to roar, respectively) and its ending point (telos).

The last and less representative category is that of English MoS verbs translated into Italian general verbs of saying, the only examples found in the corpus being to call - chiedere, dire (literally, to ask, to say); to croak rispondere (literally, to reply); to discourse - parlare (literally, to speak). In these cases, the Italian examples contain no indication of Manner of Speaking, thus omitting to realize in the verb root the Constitutive qualia ascribable to the semantic configuration of the corresponding English predicates, as examples (11), (12) and (13) show.

(11) to call

$$
\begin{aligned}
& \left(\text { Qualia }=\left(\begin{array}{l}
\text { Const }=\text { loud volume } \\
\text { Formal }=\text { say }
\end{array}\right)\right. \\
& \text { (12) to croak } \\
& \left(\text { Qualia }=\left(\begin{array}{l}
\text { Const }=\text { low, rough } \\
\text { Formal }=\text { say }
\end{array}\right)\right)
\end{aligned}
$$

(13) to discourse

$$
\left(\text { Qualia }=\left(\begin{array}{l}
\text { Const }=\text { long, formal } \\
\text { Formal }=\text { say }
\end{array}\right)\right)
$$

\section{Conclusion}

This study investigates the domain of MoS verbs in English and Italian. More specifically, it analyzes the way in which the information conflated in the $\mathrm{MoS}$ predicates used in narrative texts may be lost or enriched in the translation process between an S-F language like English and a V-F language like Italian. According to the research carried out in this paper, the following conclusions may be drawn: 
a) Italian employs a slightly larger number of MoS verb types than English;

b) in the vast majority of cases, and contrary to its typological nature of V-F language, Italian conflates the manner of speaking in a way similar to English, that is in the verb root;

c) whenever the manner of speaking is encoded in an adjunct construction, this strategy is used by translators to emphasize semantic-pragmatic or physical auditory components of the speaking event;

d) sometimes, the information encoded in the English MoS predicates is enriched in the Italian translations, as in the case of Light Verb Constructions that add an aspectual nuance with respect to the original verb;

e) loss of information through the translation process from English into Italian is rarely observed, being represented only by 4 examples out of 148 .

As suggested in Rojo and Valenzuela's (2001) work, this study confirms the importance of investigating the MoS conflation patterns at a cross-linguistic level, in that the dichotomy between S-F and V-F languages seem to be blurred in this semantic domain. In the near future, I will apply this kind of analysis to a broader corpus, as well as to other V-F languages, such as French.

\section{References}

Alba Salas, J. (2002). 'Light Verb Constructions in Romance: a Syntactic Analysis'. Ph.D. diss., Cornell University.

Alonso Ramos, M. (2004). Las construcciones con verbos de apoyo. Madrid: Visor.

Cadierno, T. \& L. Ruiz (2006). 'Motion events in Spanish L2 acquisition.' Annual Review of Cognitive Linguistics 4: 183-216.

Choi, S. \& M. Bowerman (1991). 'Learning to express motion events in English and Korean: The influence of language-specific lexicalization patterns.' Cognition 41: 83-121.

A.A.V.V. (1994). Collins Cobuild English Dictionary. London: Collins.

Coetzee, J.M. (1999). Disgrace. E-book [http://www.truly-free.org]. Vergogna (2000). Torino: Einaudi. [in Italian].

Coetzee, J.M. (2003). Elizabeth Costello. E-book [http://www.truly-free.org]. Elizabeth Costello (2004). Torino: Einaudi. [in Italian].

De Mauro, T. (1999). Capire le parole. Bari: Laterza. [in Italian].

De Miguel, E. (2008). 'Construcciones con verbos de apoyo en español. De cómo entran los nombres en la órbita de los verbos.' In: I. Olza Moreno, M.

Casado Velarde \& R. González Ruiz (eds.), Actas del XXXVII Simposio Internacional de la Sociedad Española de Lingüistica (SEL), 567-578.

Pamplona: Servicio de Publicaciones de la Universidad de Navarra.

Iacobini, C. (2010). 'The number and use of manner verbs as a cue for typological change in the strategies of motion events encoding.' In: G. Marotta,

A. Lenci, L. Meini \& F. Rovai (eds.), Space in language, 495-514. Pisa: ETS. 
Jespersen, O. (1954). A Modern English Grammar on Historical Principles. London: Allen \& Unwin.

A.A.V.V. (1994). Language Activator. London: Longman.

Lehrer, A. (1988). 'Checklist for verbs of speaking.' Acta Linguistica Hungarica 38: 143-161.

Levin, B. (1993). English Verb Classes and Alternations. Chicago: University of Chicago Press.

Li, P. \& L. Gleitman (2002). 'Turning the tables: language and spatial reasoning.' Cognition 83: 265-294.

A.A.V.V. (2002). MacMillan English Dictionary. Oxford: Oxford University Press.

Moravcsik, J.M. (1975). 'Aitia as generative factor in Aristotle's Philosophy.' Dialogue 14: 622-636.

Mufwene, S.S. (1978). 'English Manner-of Speaking Verbs Revisited.' In: D. Farkas, W. M. Jacobsen, K. W. Todrys (eds.), Parasession on the Lexicon, 278-288. Chicago: Chicago Linguistic Society.

A.A.V.V. (2010). Oxford Dictionary of English. 2nd Edition. Oxford: Oxford University Press.

A.A.V.V. (2004). Oxford English Dictionary. Cd-rom version 3.1. Oxford: Oxford University Press.

Papafragou, A. \& S. Selimis (2010). 'Event categorization and language: A cross linguistic study of motion.' Language and Cognitive Processes 25(2): 224-260.

Papafragou, A. Massey, C. \& L. Gleitman. (2006). 'When English proposes what Greek presupposes: The cross-linguistic encoding of motion events.' Cognition 98: 75-87.

Pavlenko, A. (2010). 'Verbs of motion in L1 Russian of Russian-English Bilinguals.' Bilingualism:Language and Cognition 13(1): 49-62.

Pustejovsky, J. (1998). The Generative Lexicon. Cambridge, MA: The MIT Press.

Rojo, A. \& J. Valenzuela. (2001). 'How to say things with words: ways of saying in English and Spanish.' META 46 (3): 467-477.

Rowling, J.K. (1997). Harry Potter and the Sorcerer's Stone. Canada: Penguin Books. Harry Potter e la Pietra Filosofale. (1998). Milano: Salani Editore. [in Italian].

Rowling, J.K. (1998). Harry Potter and the Chamber of Secrets. Canada: Penguin Books. Harry Potter e la Camera dei Segreti. (1999). Milano: Salani Editore. [in Italian].

Samek-Lodovici, V. (2003). 'The internal structure of arguments and its role in complex predicate formation.' Natural Language and Linguistic Theory 21: 835881.

Slobin, D. (1996a). 'From thought and language to thinking for speaking.' In: J.J. Gumperz \& S.C. Levinson (eds.). Rethinking linguistic relativity, 70-96. Cambridge: Cambridge University Press.

Slobin, D. (1996b). 'Two ways to travel: Verbs of Motion in English and Spanish.' In: M. Shibatani \& S.A. Thompson (eds.), Grammatical Constructions: Their form and meaning, 195-219. New York: Oxford University Press.

Slobin, D. (1997). 'Mind, code, and text.' In: Bybee J., Haiman J. \& S.A.

Thompson (eds.), Essays on language function and language type: dedicated to $T$. Givón, 437-467. Amsterdam: John Benjamins.

Slobin, D. (2000). 'Verbalized events: A dynamic approach to linguistic relativity and determinism.' In: Niemeier, S. \& R. Dirven (eds.), Evidence for linguistic relativity, 107-138. Berlin: Mouton de Gruyter.

Slobin, D. (2005). 'Relating events in translation.' In: Ravid, D.D. \& H.B. 
Shyldkrot (eds.), Perspectives on language and language development: Essays in honor of Ruth A. Berman, 115-129. Dordrecht: Kluwer.

Snell-Hornby, M. (1983). Verb-descriptivity in German and English: a contrastive study in semantic fields. Heidelberg: C. Winter Universitatsverlag.

Strömqvist, S. \& L. Verhoeven (eds.). (2004). Relating events in narrative: Typological and contextual perspectives. Mahwah, NJ: Lawrence Erlbaum.

Talmy, L. (2000). Toward a cognitive semantics. Vol. II Typology and process in concept structuring. Cambridge, MA: The MIT Press. A.A.V.V. (2010). The New Oxford American Dictionary. 3rd Edition. Oxford: Oxford University Press.

Urban, M. \& J. Ruppenhofer. (2001). 'Shouting and Screaming: Manner and Noise Verbs in Communication.' Literary and Linguistic Computing 16 (1): 73-94.

Vendler, Z. (1967). Linguistics in Philosophy. Ithaca: Cornell University Press.

Vergaro, C. Sandford, J.L. Mastrofini, R. \& Y.M. Formisano. Forthcoming. 'Trill, purr and wail: Manner of speaking verbs in English.'

Zwicky, A.M. (1971). 'In a manner of speaking.' Linguistic Inquiry 2: 223-233.

\section{Sitography}

http://dictionary.com. [30 August 2012].

http://merriam-webster.com. [30 August 2012].

http://wordreference.com. [30 August 2012]. 